http://jmscr.igmpublication.org/home/ ISSN (e)-2347-176x ISSN (p) 2455-0450 crossref DOI: https://dx.doi.org/10.18535/jmscr/v8i3.53

\title{
Evaluation of surface epithelial ovarian tumors and its correlation with preoperative serum CA125 levels in a tertiary care centre
}

\author{
Authors \\ Dr Shalini Kapoor, Dr Neelam Sharma*, Dr Rajni Kaushik, Dr Rajeev Sood, \\ Dr Anupam Prashar, Dr Nalneesh Sharma \\ Department of Pathology, IGMC, Shimla \\ *Corresponding Author \\ Dr Neelam Sharma \\ Professor, Department of Pathology, IGMC, Shimla, India
}

\begin{abstract}
Introduction: Ovarian cancer is ranked third most frequent female cancer in India. The incidence varies between 2. 2 to 7.8 per lakh population in various parts of India and there is steady increase in age standardized incidence rate of ovarian carcinoma. The present study was aimed to evaluate the histomorphology of epithelial ovarian tumors and to find the relationship between serum CA-125 levels with histopathology and staging of these neoplasms.

Material \& Methods: 105 cases of surface epithelial ovarian tumors were evaluated over a period of one year from July 2018 to June 2019 in the Department of Pathology I.G.M.C Shimla. Preoperative serum CA125 levels were noted.Malignant tumors were staged using FIGO staging.

Results: Serous tumors were the most common tumors reported in the study constituting 67 cases (63.8\%). Benign tumors (64.76\%) comprised the major group followed by malignant tumors (29.52\%) and borderline tumors (5.7\%).. Serum CA125 concentration in benign, borderline and malignant tumors were compared and statistically significant difference was found $(p=0.000)$. CA125 showed positive correlation with the stage $(p=0.024)$ of ovarian cancer. However no significant correlation was found between subtype of benign, borderline and malignant tumors with serum CA125 levels.

Conclusion: Patients with borderline /malignant epithelial tumors had higher preoperative serum CA125 value as compared to benign ovarian tumors.

Keywords: surface epithelial ovarian tumors, serum CA125, age distribution, FIGO staging.
\end{abstract}

\section{Introduction}

Ovarian cancer poses a great challenge to the healthcare system as it accounts for the significant number of deaths from the malignancies of female genital tract. According to the national cancer registry data, it is ranked third most frequent female cancer in India following carcinoma cervix and breast. The incidence varies between 2.2 to 7 . 8 per lakh population in various parts of India and there is steady increase in age standardized incidence rate of ovarian carcinoma. ${ }^{1}$ About $80 \%$ of tumors are benign occurring in the young women between the ages of 20 to 45 years whereas borderline tumors occurs in slightly 


\section{JMSCR Vol||08||Issue ||03||Page 303-310||March}

older age group. Incidence of malignant tumors increase with age, occurring predominantly in premenopausal and peri-menopausal women.

Cancer Antigen-125 (CA125) is the most frequently used biomarker for ovarian cancer detection. Its level increases in about $90 \%$ of the women with advanced ovarian epithelial tumors and in $50 \%$ of patients in the early stages particularly in tumors of serous nature. Response to the treatment and prognosis can also be determined by monitoring CA 125 levels ${ }^{2,3}$

\section{Material and Methods}

Present cross sectional study was conducted in department of pathology over a period of one year from July 2018 to June 2019. A total of 105 ovarian tumor samples obtained through cystectomy, oophorectomy and pan hysterectomy specimens received in the department were evaluated. Relevant clinical details were retrieved from the records. All the lesions diagnosed as surface epithelial ovarian tumors on histopathological examination with pre-operative assessment of serum CA125 levels were included in the study.

The specimens received were adequately fixed in $10 \%$ neutral buffered formalin. Gross findings were noted and adequate representative sections were taken. The tissue sections were processed, paraffin embedded, 2-4 micron thin section were cut and stained with haematoxylin and eosin stain using standard protocol. The tumors were categorized according to WHO classification. The sensitivity, specificity and diagnostic accuracy of serum CA125 was calculated in percentage with reference to histomorphology of specimens. $p$ value $<0.05$ was considered to be statistically significant.

\section{Observation and Results}

Age of all patients ranged from 18-90 years, with mean age being $47.56 \pm 14.88$ years. Majority of the patients i.e 57 out of $105(44.76 \%)$ were seen in 40-60years age group.
Histological classification was performed in accordance with the WHO classification of ovarian tumors. Serous tumors were the most common tumors encountered in the study constituting 67 cases $(63.8 \%)$, mucinous tumors 29 cases $(27.6 \%)$, transitional cell tumor 6 cases (5.7\%), endometrioid tumor 2 cases $(1.9 \%)$ and clear cell carcinoma 1 case $(0.9 \%)$ (Table 1 Fig 1)

Table 1: Spectrum of ovarian tumors $(n=105)$

\begin{tabular}{|c|c|c|}
\hline TYPE OF TUMOR & $\begin{array}{c}\text { NO. } \\
\text { OF } \\
\text { CASES }\end{array}$ & PERCENTAGE \\
\hline SEROUS TUMORS & 67 & 63.8 \\
\hline \multicolumn{3}{|l|}{ a. Benign } \\
\hline Serous cyst adenoma & 41 & 39 \\
\hline \multicolumn{3}{|l|}{ b. Borderline } \\
\hline $\begin{array}{l}\text { Atypical proliferative Serous } \\
\text { tumors }\end{array}$ & 2 & 1.9 \\
\hline \multicolumn{3}{|l|}{ c. Malignant } \\
\hline Serous carcinoma & 24 & 22.9 \\
\hline MUCINOUS TUMORS & 29 & 27.6 \\
\hline \multicolumn{3}{|l|}{ a. Benign } \\
\hline Mucinous cyst adenoma & 21 & 20 \\
\hline \multicolumn{3}{|l|}{ b. Borderline } \\
\hline $\begin{array}{l}\text { Atypical proliferative } \\
\text { mucinous tumor }\end{array}$ & 4 & 3.8 \\
\hline \multicolumn{3}{|l|}{ c. Malignant } \\
\hline Mucinous carcinoma & 4 & 3.8 \\
\hline TRANSITIONAL & 6 & 5.7 \\
\hline \multicolumn{3}{|l|}{ a. Benign } \\
\hline Brenner & 6 & 5.7 \\
\hline b. Borderline & 0 & 0 \\
\hline c. Malignant & 0 & 0 \\
\hline CLEAR CELL & 1 & 0.9 \\
\hline a. Benign & 0 & 0 \\
\hline b. Borderline & 0 & 0 \\
\hline \multicolumn{3}{|l|}{ c. Malignant } \\
\hline Clear cell carcinoma & 1 & 0.9 \\
\hline ENDOMETRIOID & 2 & 1.9 \\
\hline a. Benign & 0 & 0 \\
\hline b. Borderline & 0 & 0 \\
\hline \multicolumn{3}{|l|}{ c.Malignant } \\
\hline Endometroid & 2 & 1.9 \\
\hline $\begin{array}{l}\text { SEROMUCINOUS } \\
\text { TUMORS }\end{array}$ & $\mathbf{0}$ & $\mathbf{0}$ \\
\hline UNDIFFERENTIATED & $\mathbf{0}$ & $\mathbf{0}$ \\
\hline
\end{tabular}




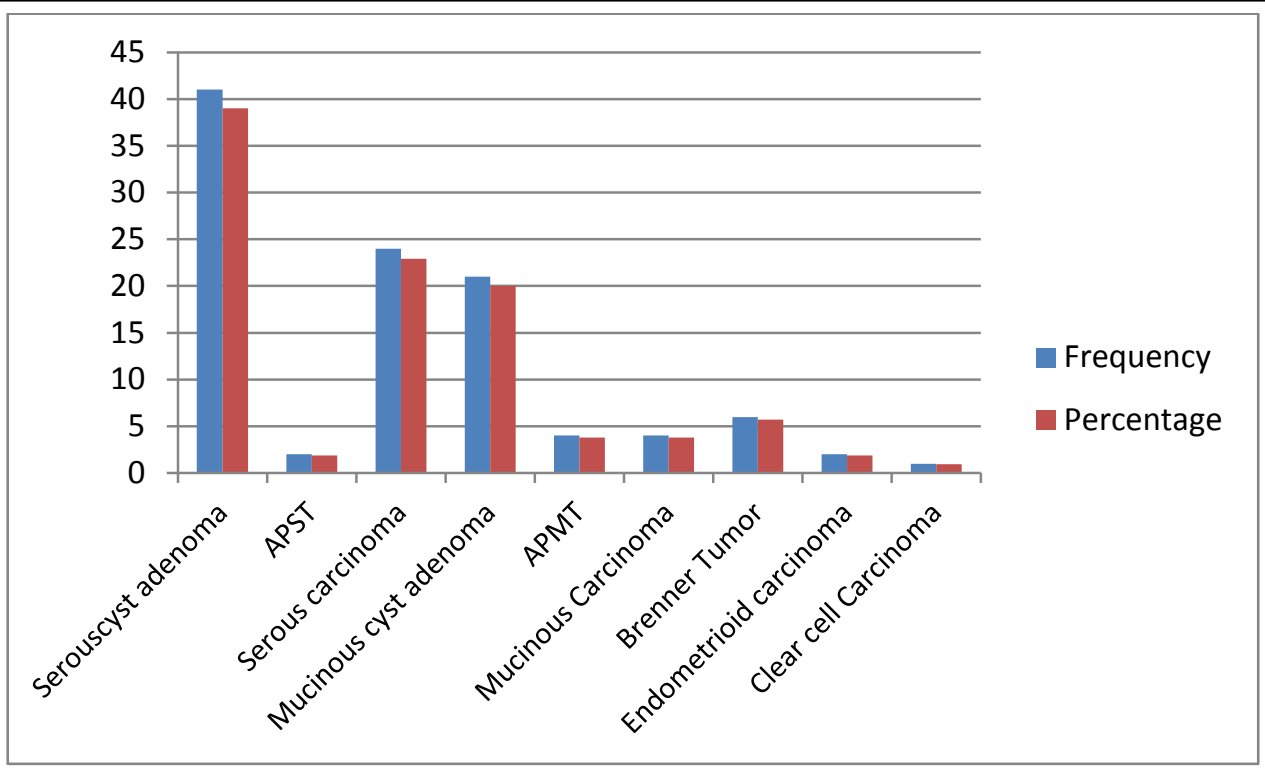

Tumors were further categorized as benign, borderline, \& malignant based on their biological behaviour. Benign tumors $(64.76 \%)$ constituted the major group followed by malignant tumors $(29.52 \%)$ and borderline tumors $(5.7 \%)$.

Mean age for Benign, Borderline and Malignant tumours were found to be $43.8,45.5$, and 56.1 years respectively. Statistically significant difference was observed between biological behaviour and age of presentation of ovarian tumors $(p=0.0004)$. Incidence of malignant neoplasms increases as the age progresses. Table 2

Table 2: Age wise distribution of surface epithelial ovarian tumors $(n=105)$

\begin{tabular}{|l|c|c|c|c|c|c|}
\hline & Total & $<\mathbf{4 0}$ years & $\mathbf{4 0 - 6 0}$ years & $>\mathbf{6 0}$ years & Mean age(years) & p-value \\
\hline Benign & 68 & 27 & 33 & 8 & 43.8 & 0.0004 \\
\hline Borderline & 6 & 2 & 3 & 1 & 45.5 & \\
\hline Malignant & 31 & 1 & 21 & 9 & 56.1 & \\
\hline Total & $\mathbf{1 0 5}$ & $\mathbf{3 0}$ & $\mathbf{5 7}$ & $\mathbf{1 8}$ & & \\
\hline
\end{tabular}

\section{Serum CA125 correlation with ovarian tumors}

Preoperative serum CA125 levels were recorded taken as normal. 44 out of total 105 cases showed in all the patients. Value less than $35 \mathrm{U} / \mathrm{ml}$ were increased serum CA125 values. Table 3

Table 3: Distribution of serum CA 125 levels in surface epithelial ovarian tumors $(n=105)$

\begin{tabular}{|l|c|c|c|c|c|c|}
\hline CA125 levels & \multicolumn{2}{|c|}{$<35 \mathbf{3} / \mathbf{m l}$} & \multicolumn{2}{c|}{$>\mathbf{3 5 U} / \mathbf{m l}$} & \multirow{2}{*}{$\begin{array}{c}\text { Mean } \\
\text { CA125 U/ml }\end{array}$} & \\
\cline { 1 - 5 } Ovarian lesion & No of cases & \%age & No of cases & \%age & \\
\cline { 1 - 5 } Benign & 59 & 86.7 & 9 & 13.2 & 31.2 & \multirow{2}{*}{0.0000} \\
\cline { 1 - 5 } Borderline & 2 & 33.3 & 4 & 66.6 & 110.80 & \\
\hline Malignant & 0 & 0 & 31 & 100 & 1258.26 & \\
\hline Total & 61 & & 44 & & & \\
\hline
\end{tabular}

Majority of benign cases, 59 (86.7\%) had serum CA125 levels within normal limits. Values $>35 \mathrm{U} / \mathrm{ml}$ were seen in all the malignant cases with majority having markedly raised levels above $500 \mathrm{U} / \mathrm{ml}$. These cases were associated with stage III and stage IV tumors. 4 out of total 6 borderline tumors showed serum CA125 levels above
$35 \mathrm{U} / \mathrm{ml}$ with range varying from $45.2 \mathrm{U} / \mathrm{ml}$ to $372.6 \mathrm{U} / \mathrm{ml}$.

Mean values of serum CA125 in benign $(31.2 \mathrm{U} / \mathrm{ml})$, borderline $(110.80 \mathrm{U} / \mathrm{ml})$ and malignant $(1258.26 \mathrm{U} / \mathrm{ml})$ tumors were compared and statistically significant association was found. $(\mathrm{p}=0.000)$, more the malignant potentiality of the 
tumor have higher values of CA125.

\section{Benign tumors}

Serous cyst adenoma constituted the predominant group $41(60.3 \%)$ among benign neoplasms followed by mucinous cyst adenomas $21(30.9 \%)$ and Brenner tumor $6(8.8 \%)$.Mean age of presentation in benign tumors was 43.8 years. Benign serous tumours are usually small and the mucinous tumours present as huge masses. The smallest tumour in our study was a serous cystadenoma measuring $(3 \times 2 \times 1) \mathrm{cm}$ and the largest tumour was mucinous cystadenoma measuring $(38 \times 30 \times 4) \mathrm{cm}$. Grossly serous cyst adenoma were predominantly unilocular cystic structures in 38 out of 41 cases. Three cases had both cystic and solid components.

In the present study majority of serous and mucinous cyst adenomas revealed normal levels of tumor marker. TABLE 4

Table 4: Serum CA125 in benign tumors $(n=68)$

\begin{tabular}{|l|c|c|c|c|}
\hline Serum CA125 & \multicolumn{2}{|c|}{$<35$ U/ml } & \multicolumn{2}{c|}{$>$ 35U/ml } \\
\hline Ovarian tumor & No of cases & Percentage & No of cases & Percentage \\
\hline Serous cyst adenoma & 34 & 50 & 7 & 10.1 \\
\hline Mucinous cyst adenoma & 19 & 27.9 & 2 & 3 \\
\hline Brenner tumor & 6 & 8.8 & - & - \\
\hline Total & 59 & & 9 & \\
\hline
\end{tabular}

Only 7 cases of serous cyst adenomas and 2 cases of mucinous cyst adenoma showed CA125 value more than $35 \mathrm{U} / \mathrm{ml}$. Serum levels were found to be within normal limits in all 6 cases of Brenner tumor.

Mean Serum levels in serous cyst adenoma, mucinous cyst adenoma and Brenner tumor was $28.1 \mathrm{U} / \mathrm{ml}, 44.3 \mathrm{U} / \mathrm{ml}$ and $8.2 \mathrm{U} / \mathrm{ml}$ respectively. No significant correlation was found between subtype of benign tumors and serum CA125 levels $(\mathrm{p}=0.725)$

\section{Borderline tumors}

Borderline tumors accounted for 6( $5.7 \%)$ out of total 105 cases and included 4 cases of Atypical poliferative mucinous tumors (APMT) and 2 cases of Atypical proliferative serous tumors (APST). Mean age of presentation was 45.50 years. All of these showed unilateral involvement of ovaries. Tumor size ranged between $3-20 \mathrm{~cm}$, cystic predominantly with focal solid areas.

4 out of 6 tumors showing borderline differentiation had serum CA125 levels above 35 $\mathrm{U} / \mathrm{ml}$ with range between $45.2 \mathrm{U} / \mathrm{ml}$ to $372.6 \mathrm{U} / \mathrm{ml}$.

(Table 5)

Table 5: Distribution of preoperative serum CA 125 levels in borderline tumor $(n=6)$

\begin{tabular}{|l|c|c|c|c|}
\hline Serum CA125 & \multicolumn{2}{|c|}{$<35$ U/ml } & \multicolumn{2}{c|}{$>35$ U/ml } \\
\hline & No of cases & Percentage & No of cases & Percentage \\
\hline Serous(APST) & 1 & 16.7 & 1 & 16.7 \\
\hline Mucinous(APMT) & 1 & 16.7 & 3 & 49.1 \\
\hline Total & 2 & & 4 & \\
\hline
\end{tabular}

In APST mean CA125 concentration was 195.5U/ml and in APMT was $68.4 \mathrm{U} / \mathrm{ml}$. No statistically significant association was found between CA125 and subtype of borderline tumors $(\mathrm{p}=0.331)$.

\section{Malignant tumors}

Comprised 31 out of total 105 (29.52\%) cases. Majority of malignant neoplasms were of serous carcinoma 24(77.4\%) followed by mucinous carcinoma 4(12.9\%), endometrioid carcinoma 2 $(6.5 \%)$ and clear cell carcinoma1 $(3.2 \%)$.

Most of the serous carcinomas were bilateral and had mixed solid and cystic consistency.23 out of 24 serous carcinomas were high grade tumors. Mean age of presentation of malignant tumors was 56.2 years. Majority of serous and all mucinous 
carcinoma were seen in 5 th decade or later age group. Single case of clear cell carcinoma presented in 62 years of age. Oldest patient $(90$ years) in our study was of endometrioid carcinoma.
All the malignant neoplasms revealed raised serum levels of CA125 ranging from $69.3 \mathrm{U} / \mathrm{ml}$ to 6809U/ml (Table 6)

Table 6: Serum CA125 in malignant surface epithelial ovarian tumors $(n=31)$

\begin{tabular}{|l|c|c|c|c|c|}
\hline Serum CA125 & \multicolumn{2}{|c|}{$<35$ U/ml } & \multicolumn{2}{c|}{$>$ 35U/ml } & $\begin{array}{c}\text { Mean } \\
\text { Serum CA125 } \\
\text { Levels }\end{array}$ \\
\hline Ovarian tumor & No of cases & percentage & No of cases & Percentage & 1427.30 \\
\hline Serous carcinoma & - & - & 24 & 77.4 & 465.2 \\
\hline Mucinous carcinoma & - & - & 4 & 12.9 & 1804.8 \\
\hline Clear cell carcinoma & - & - & 1 & 3.2 & 542.6 \\
\hline Endometrioid carcinoma & - & - & 2 & 6.5 & $\mathbf{1 0 0}$ \\
\hline Total & & & $\mathbf{3 1}$ & & \\
\hline
\end{tabular}

In 15 of 24 cases $(48.4 \%)$ of Serous carcinoma and in clear cell carcinoma preoperative serum CA125 levels were markedly raised above $500 \mathrm{U} / \mathrm{ml}$. No association was found between CA125 level and histologic subtype among malignant tumors $(\mathrm{p}=0.615)$

\section{Serum CA125 correlation with FIGO staging}

Malignant tumors were staged according to FIGO criteria into stage I, II, III \& IV. Maximum number of patients $21(67.8 \%)$ were seen in stage III and IV followed by stage I in $7(22.5 \%)$ patients and stage II in 3(9.7\%).

Mean serum CA125 concentration in Stage I, II, III, IV was 464.05, 218.13, 1397.40 and 3316.76 $\mathrm{U} / \mathrm{ml}$ respectively and showed significant positive correlation with stage $(\mathrm{p}=0.024)$.

\section{Discussion}

Ovarian tumors are heterogenous group of neoplasms of epithelial, stromal \& germ cell origin. Even in a single group of tumors inherent heterogeneity exists with biological behaviour ranging from benign to highly aggressive malignant tumor. Cancer Antigen-125(CA125) is the most frequently used biomarker for ovarian cancer detection. It has an established role in monitoring treatment, detecting recurrence of ovarian cancer and as a prognostic marker for advanced ovarian cancer.

Most of the studies published on ovarian tumors also observed serous tumors to be the predominant group among ovarian tumors followed by mucinous type . Percent incidence of these tumors $(63.8 \% \& 27.6 \%)$ in the present study are comparable to that reported by Jha et $\mathrm{al}^{4}$ and Nalini $^{5}$ et al. Endometrioid tumor and Clear cell tumor constituted $1.9 \& 0.9 \%$ cases respectively in comparison to the studies conducted by Nalini ${ }^{5}$ $\&$ Rao $\mathrm{NK}^{6}$ et al. (Table 7)

Most of the tumors in this study showed benign morphology followed by malignant \& borderline tumors correlating well with other published studies. Percent incidence of these tumors in our study was consistent with the observation by Mankar 7 et al 2015.

Table 7: Spectrum of surface epithelial ovarian tumors

\begin{tabular}{|l|c|c|c|c|c|c|c|}
\hline & Year & $\begin{array}{c}\text { No of } \\
\text { cases }\end{array}$ & $\begin{array}{c}\text { Serous } \\
\text { tumors } \\
\text { \%age }\end{array}$ & $\begin{array}{c}\text { Mucinous } \\
\text { tumors } \\
\text { \%age }\end{array}$ & $\begin{array}{c}\text { Transitional } \\
\text { Tumors } \\
\text { \%age }\end{array}$ & $\begin{array}{c}\text { Endometrioid } \\
\text { Tumors } \\
\text { \%age }\end{array}$ & $\begin{array}{c}\text { Clear cell } \\
\text { Tumors } \\
\text { \%age }\end{array}$ \\
\hline Jha et al & 2008 & 84 & 67.5 & 32.5 & - & - & - \\
\hline Pradhan et al & 2012 & 39 & 46.1 & 38.4 & 5.2 & - & - \\
\hline Nalini et al & $\mathbf{2 0 1 6}$ & $\mathbf{1 4 1}$ & $\mathbf{6 1 . 7}$ & $\mathbf{3 2 . 6}$ & $\mathbf{2 . 1}$ & $\mathbf{0 . 7}$ & $\mathbf{0 . 7}$ \\
\hline Rao NK et al & 2017 & 244 & 55.7 & 38.5 & 1.6 & 2.5 & 0.8 \\
\hline Present study & $\mathbf{2 0 1 9}$ & $\mathbf{1 0 5}$ & $\mathbf{6 3 . 8}$ & $\mathbf{2 7 . 6}$ & $\mathbf{5 . 7}$ & $\mathbf{1 . 9}$ & $\mathbf{0 . 9}$ \\
\hline
\end{tabular}


Age of the patients in present study ranged from $18-90$ years, with a mean of $47.56 \pm 14.88$ years. This is comparable to the study conducted by Nalini $^{5}$ et al in which the age ranged between 14 to 76 years with mean age being 42 years. Jha et $\mathrm{al}^{4}$ reported mean age of 53.35 years in their study of 86 patients with ovarian tumors.

\section{Benign tumors}

Total 68 benign tumors were reported in our study. 41 cases $(60.3 \%)$ were of Serous cyst adenoma, 21 cases $(30.9 \%)$ of mucinous cystadenoma \& 6 cases $(8.8 \%)$ of Brenner tumor were reported. These results were in concordance with study carried out by Nalini et al and Tiwari et $\mathrm{al}^{8}$. In their study of 117 cases, Nalini et al (2016) found $60.6 \%$ of serous cyst adenoma, $34.1 \%$ mucinous cyst adenoma, 2.5\% Brenner tumour and $2.5 \%$ seromucinous cystadenoma. Tiwari et $\mathrm{al}^{8}$ (2016) also found similar results with serous cyst adenoma(61.2\%) being the most common benign tumor followed by mucinous cyst adenoma (35.4\%).

In the present study $86.9 \%$ of benign tumors showed serum CA125 levels within normal limits and increased in rest $13.1 \%$ cases. Elevated preoperative levels were found in 7 patients of serous cyst adenoma and 2 patients of mucinous cyst adenoma. Roy et $\mathrm{al}^{9} 2015$ reported increase in Serum levels in $5.41 \%$ benign cases whereas Verma et $\mathrm{al}^{10}$ reported increase in $10 \%$ cases, similar to our study.

\section{Borderline tumors}

In this study, 6 out of a total of 105 cases were borderline tumors which included APMT 66.6\% and APST $33.3 \%$ and correlated well with the studies conducted by Nalini et al and Tiwari et al. They both reported high percent incidence of APMT (57.1\% \& 60\%). In comparison Rao NK et al showed higher percent incidence of APST $(6.6 \%)$ among six study cases of borderline tumors.

APMT were more common in 40-60 years age group and was in concordance with study done by Pradhan et $\mathrm{al}^{11} \&$ Rao NK et al.Mean age of presentation in $\mathrm{BOT}_{\mathrm{S}}$ was 45.50 years close to the mean age of 48.6 years reported by Tiwari et al. In present study elevated CA125 levels were observed in 1/2 (50\%) case of APST and 3/4 (75\%) cases of APMT. In comparison Kolwijck et $\mathrm{al}^{12}$ found elevated serum levels of CA125 in 70 $\%$ of serous borderline tumors and $34 \%$ of mucinous borderline tumors. They also stated that the preoperative serum CA125 levels are significantly higher in advanced lesions \& in serous tumors.

\section{Malignant ovarian tumors}

Serous carcinoma was the most frequent (24/31, $77.4 \%$ ) histological type of malignancy reported in this study. Nalini et al, Rao NK et al and Mankar et $\mathrm{al}^{7}$ also reported $76.47 \%, 81.8 \%$ and $64.6 \%$ of serous carcinoma, being the most common malignancy observed in their study. Mucinous carcinoma (12.9\%) was the second common tumour reported by our study and consistent with the observation conducted by Nalini et al and Rao NK et al .Two cases of endometrioid carcinoma and one case of clear cell carcinoma were encountered in present study and by Nalini et al. Rao NK et al also found 2 cases of transitional cell tumour in their study. However we did not find any case of transitional cell carcinoma .

Mean age of malignant tumors was 56.2 years comparable to that reported by Tiwari et al 2016 (59.3 years) .Majority of serous and all mucinous carcinoma were seen in $5^{\text {th }}$ decade and later age consistent with the study carried out by Pradhan et al. Single case of clear cell carcinoma was reported in 62 years of age whereas Rao NK et al reported this in $4^{\text {th }}$ decade. In our study all the malignant tumors $(100 \%)$ were associated with markedly raised serum CA125 levels \& was in confirmation with the study conducted by Cambruzzi et $\mathrm{al}^{13}$ on 60 study cases. Studies carried out by Roy et al, and Verma et al also observed serum levels $>35 \mathrm{U} / \mathrm{ml}$ in $70.6 \%$ and $71.43 \%$ cases respectively.

Serum CA125 concentration in benign, borderline 
and malignant tumors were compared and statistically significant association was found $(\mathrm{p}=0.000)$. Cambruzzi et al 2014 also described a significant association between serum level of CA125 and biological behavior of ovarian tumors $(p=0.0002)$, suggesting that high levels of tumor marker are associated with malignant neoplasms and lesions having more aggressive biological behaviour.

\section{FIGO stage}

FIGO stage is one of the universally accepted prognostic factors for patients with ovarian carcinoma. Early stage of ovarian tumors is associated with good prognosis because surgical treatment is enough for patients in stages I and II. Patients with advanced-stage disease often require debulking, or cytoreductive surgery, as well. ${ }^{7}$
Most of the similar studies observed the clinical presentation of ovarian cancers in advanced stages and only few studies found the patients in early stage of disease .In our study also ,majority of the patients presented in FIGO stage III \& IV followed by stage I which is in conformity with the observation made by Atla $\mathrm{B}^{14}$ et al \& Vasquez $\mathrm{FM}^{15}$ et al. Stage I tumours were reported to be more common in the study carried out by Cambruzzi $\mathrm{E}^{13}$ et al ( 2014) on 60 cases.

This study showed significant correlation of serum CA125 with FIGO staging $(\mathrm{p}=0.024)$ in concordance with the observation by Igor But ${ }^{16}$ et al. In contrast Osman ${ }^{17}$ et al did not found any statistical significant relationship between CA125 and FIGO Stage $(\mathrm{p}==0.08)$

Table 8: Comparison of diagnostic accuracy of Preoperative Serum CA 125 levels

\begin{tabular}{|l|c|c|c|c|c|}
\hline Authors & Year & No of cases & $\begin{array}{c}\text { Sensitivity } \\
\mathbf{\%}\end{array}$ & $\begin{array}{c}\text { Specificity } \\
\mathbf{\%}\end{array}$ & $\begin{array}{c}\text { Diagnostic } \\
\text { Accuracy } \\
\mathbf{\%}\end{array}$ \\
\hline Rama mani et al & 2007 & 75 & 90.66 & 81.48 & - \\
\hline Tiwari et al & 2016 & 58 & 94.7 & 49.3 & 59.3 \\
\hline Present study & $\mathbf{2 0 1 9}$ & $\mathbf{1 0 5}$ & $\mathbf{1 0 0}$ & $\mathbf{8 2 . 4 3}$ & $\mathbf{8 7 . 6 2}$ \\
\hline
\end{tabular}

In this study the sensitivity and specificity of CA125 to predict malignant behaviour of ovarian neoplasm was $100 \%$ and $82.43 \%$ respectively. Rama mani \& Tiwari et al in their study group observed sensitivity to be $90.6 \%$ \& $94.7 \%$ respectively. However specificity $(81.48 \%)$ in the study performed by Rama mani et al is correlating well with our study. (Table 8 )

\section{Conclusion}

Higher value of preoperative serum CA125 levels were associated with borderline / malignant surface epithelial ovarian tumors especially serous type and high grade tumors. Serum CA125 levels correlated well with biological behaviour of tumors and ovarian cancer staging (FIGO). Proper recognition and classification of ovarian tumors is essential for appropriate management as malignant tumors are usually picked up at an advanced stage owing to their asymptomatic nature and inaccessible site for aspiration cytology and biopsy. Early screening is necessary especially in developing countries to increase the survival rate.

\section{Bibliography}

1. Consolidated report of population based cancer registries 2012-2014. National cancer registry program Banglore ICMR. ncdirindia.org NCRP_Annual reports.

2. Bast RC, Jr, Feeney M, Lazarus H, Nadler LM, Colvin RB, Knapp RC.Reactivity of a monoclonal antibody with human ovarian carcinoma. J Clin Invest. 1981;68:13311337.

3. Bast R, Klug T, St John E, et al. A radioummunoassay using a monoclonal antibody to monitor the course of epithelial ovarian cancer. $\mathrm{N}$ Engl J Med. 1983;309(15):883-887. 
4. Jha R, Karki S. Histological pattern of ovarian tumors and their age distribution. Nepal Med Coll J. 2008; 10(2):81-85.

5. Modepalli N, Venugopal SB. Clinicopathological Study of Surface Epithelial Tumours of the Ovary: An Institutional Study. Journal of Clinical and Diagnostic Research. 2016 Oct, Vol10(10): EC01-EC04.

6. Nageshwararao K, Srinivasarao C." Ovarian surface epithelial tumor incidence in tertiary care hospital in Andhra Pradesh."Iosr Journal of dental and Medical Sciences (IOSR-JDMS) 16.12(2017);16-20.

7. Mankar DV, Jain GK. Histopathological profile of ovarian tumours: A twelve year institutional experience. Muller J Med Sci Res 2015;6:107-11.

8. Tiwari RK, Saha K, Mukhopadhyay D, Datta C, Chatterjee U, Ghosh TK. Evaluation of preoperative serum levels of CA125 and expression of p53 in ovarian neoplasms: A prospective clinicopathological study in a tertiary care hospital. J Obstet Gynaecol India. 2016 Apr; 66(2):107-14.doi:10.1007/s13224014-0611-7.Epub2014Oct7.

9. Roy SK, Mandal K, Mandal K. Correlation between histopathological type and grade of different ovarian tumors with their blood CA125 levels. JMSCR, 2015; 3(2) : 4078-86

10. Verma N, Kumar M, Sagar M, Babu S, Singhai A, Singh N, et al. Expression of estrogen receptor, progesterone receptor, and human epidermal growth factor receptor type $2 /$ neu in surface epithelial ovarian tumours and its clinicohistopathological correlation. Indian J Health Sci Biomed Res 2018;11:19-24.
11. Pradhan A, Sinha AK, Upreti D. Histopathological spectrum of ovarian tumors at BPKIHS. Health Renaissance 2012;10(2):87-97.

12. Kolwijick, E. et al. Preoperative CA-125 level in 123 patients with borderline ovarian tumors: a retrospective analysis and review of the literature. Int $\mathrm{J}$ Gynecol Cancer, v.19, n. 8, p. 1335-8, 2009.

13. Cambruzzi E, Lima RD, Teixeira SL, Pegas KL. The relationship between serum levels of CA 125 and the degree of differentiation in ovarian neoplasms. J Bras Patol Med Lab, 2014;50(1):20-25.

14. Atla B, Sarkar RN, Rasaputra M. Clinicopathological and IHC study (estrogen receptors, progesterone receptor, HER2/NEU) in malignant ovarian tumors. Int J Res Med Sci 2016;4: 1068-73.

15. Vasquez FM, Pedernera E, Obregon JR, Lopez-Basave HN, Gomora MJ, Carlon E et al. High levels of pretreatment CA125 are associated to improved survival in high grade serous ovarian carcinoma. Journal of ovarian Research (2016); 9:41.

16. Igor But, M.D., M.Sc.; Borut Gorišek, M.D., Ph.D. Preoperative Value of CA 125as a Reflection of Tumor Grade in Epithelial Ovarian Cancer gynecologic oncology November 1996 Volume 63, Issue 2, Pages 166-172 DOI: http://dx.doi.org/10.1006/gyno.1996.0301

17. Osman N, O'Leary N, Higgins MJ, Barrett N, Wallis F, Hickey K, Gupta RK. Correlation of serum CA125 levels with stage, grade and survival of patients with epithelial ovarian cancer. Journal of Clinical Oncology. 2007 Jun 20;25 (18_suppl): 16066. 